\title{
Comparative palynomorphological study of two species in the valley of Zagoria, Gjirokastra, Albania
}

\author{
Nikoleta Kallajxhiu ${ }^{1,}{ }^{*}$, Gëzim Kapidani ${ }^{2}$, Silvana Turku ${ }^{1}$ and Anxhela Dauti ${ }^{3}$ \\ ${ }^{1}$ Department of Biology, FNS, University of Elbasan "Aleksandër Xhuvani", Albania. \\ ${ }^{2}$ Department of Biology, FNS, University of Tirana, Albania. \\ ${ }^{3}$ Department of Chemistry, FNS, University of Elbasan "Aleksandër Xhuvani", Albania.
}

GSC Biological and Pharmaceutical Sciences, 2021, 15(03), 199-205

Publication history: Received on 09 May 2021; revised on 12 June 2021; accepted on 15 June 2021

Article DOI: https://doi.org/10.30574/gscbps.2021.15.3.0164

\begin{abstract}
In this study there are demonstrated for the first time in albanian literature the palynomorphologic characteristics of two types of plants (Centaurea epirota and Viola epirota), collected in Zagoria valley, Gjirokastra region, in Albania.

To carry out the study, light microscopy was used and it was concluded that the pollen grains of Centaurea epirota were 3 colporate, isopolar, with radial symmetry. In the polar view, the pollen grains have a circular triangular shape while in the equatorial view they have a compressed oval shape. Exine appeared scabrate.

Viola epirota consisted of 3-4 colporate, sometimes even 5 colporate pollen grains. In the polar view, the pollen grains had a circular shape of 3 or 4 angles, sometimes even 5 angles while in the equatorial view they had an elliptical shape. Exine appeared granulate.

To see the impact of ecological factor and the method of laboratory processing of pollen grains, the size of the new species studied was compared with the size of the pollen grains of Centaurea cyanus and Viola alba, Viola odorata and Viola arvensis, taken from the native literature.
\end{abstract}

Keywords: Pollen grain; 3-4-5 Colporate; Exine; Viola; Centaurea; Albania

\section{Introduction}

The Gjirokastra region is located between 3 mountain ranges: Trebeshinë-Dhëmbel-Nemërçkë, Shëndelli-LunxheriBureto and Mountain of Luce-Broad Mountin-Murganë. This area is part of the Southern Mountain Province of Albania [1].

The region is characterized by a high biodiversity and this is related to the Mediterranean climate and at high altitudes. Also, the biodiversity of this area has been influenced even by the topography, the geology etc. [2, 3].

Studies conducted over the years have shown that in this region grow in natural condition 717 species that make up approximately $22 \%$ of our flora [4]. Even the plants studied (Centaurea epirota and Viola epirota) belong to this vegetation.

The Çajup Mountain area is distinguished for the rare species of Centaurea zuccariniana DC, Crataegus heldreichii Boiss., Ptilotrichum ciclocarpum subsp pindicum, Minuartia stellata Marie \& P, Alkana pindicula etc. [4].

\footnotetext{
* Corresponding author: Nikoleta Kallajxhiu

Departament of Biology, FNS, University of Elbasan “Aleksandër Xhuvani”, Albania, 3001.
}

Copyright (C) 2021 Author(s) retain the copyright of this article. This article is published under the terms of the Creative Commons Attribution Liscense 4.0. 
Centaurea epirota belongs to the family Compositae and according to the Flora of Albania [5] in this family are included about 97 genus and in the Centaurea L. genus are included 35 species. There are many palynological studies by local and foreign authors of several species of the genus Centaurea $[6,7,8,9,10]$.

Viola epirota belongs to the family Violaceae which includes only 1 genus and approximately 25 species and 7 subspecies [11]. There are also palynological studies of local and foreign authors for the representatives of this family [12, 13, 14, 15, 16]. Mehrvarz et al., [17] have studied the morphopalynological aspect of about 17 species of the genus Viola in Iran.

The work conducted about the palynological description of Centaurea epirota and Viola epirota is the first in our country, enriching this way the native literature with palynomorphological data.

Based on what we said above the object of this study was to determine the palynomorphological features of two plant species.

The main purpose of the study was to point out the similarities and differences that existed in the palynological features of 4 species of the genus Viola and two species of the genus Centaurea.

\section{Material and methods}

In order to conduct this study, there were taken fresh materials during the field expedition organized in Çajup mountain, in the Valley of Zagoria, Gjirokastra, on May 25, 2021. For the identification of plants we were based on Malo, S [4] and Mahmutaj et al., [2] and the terminology used can be found in the dictionary of palinology presented by Kapidani, G [18].

For laboratory processing of pollen grains, 3 processing methods were performed:

- Erdtman's method of acetolysis [19]

- The simplified method of acetolysis of Avetisyan [20]

- The basic fuchsine method of Smoljaninova \& Gollubkova [21]

Several preparations have been prepared with these methods. Their fixation was realized with the glycerin gelatin according to the Kisser method [22]. Measurements of 31 pollen grains length of the equatorial and polar axis, length and width of the colpi, diameter of the pore, thickness of the exine were made.

The shape of the pollen grains and the number of apertures were studied relying on the basic fuchsine method. With the two methods of acetolysis, the elements of the sporoderm were determined. For conducting the study, a Biological Microscope (Motic BA310 Series LED-Digital) was used, with magnification of 100x, 400x and 1000x. The study was accompanied with microscopic photographs of pollen grains as well as photographs of plants taken in their habitat.

Since the size of the pollen grains (length of the equatorial and polar axis) as well as their apertures (length, width of the colpi and the diameter of the pore) are greatly influenced by the ecological factor and the method of processing [23, 24], comparisons of the pollen grains size of Centaurea epirota with those of Centaurea cyanus [9] as well as those of Viola epirota with the species arvensis, alba and odorata were taken from the local literature [16].

\section{Results and discussion}

\subsection{Palynomorphological description of Centaurea epirota Halacsy (Raus)}

\section{Genus: Centaurea L., Family: Compositae}

Centaurea epirota is a hemicryptophyta and pin-ballkanic plant [4]. It is considered as an endemic specie of Southern region of Albania [2].

The study showed that the pollen grains of Centaurea epirota were monads with radial and isopolar symmetry. They were 3 colporate, with almost longitudinal contours.

In the polar view, the pollen grains had a circular triangular shape while in the equatorial view they had a compact oval shape. The pore appeared elongated. Its length was $7.3 \mu$ while the width reached up to $3.3 \mu$. Their colpi were with smooth edges and their ends appeared sharp. Colpus length reached up to $19.4 \mu$. Distance between two colpi 
(mesocolpium) was up to $20 \mu$. The length of the equatorial axis varied from (32-40) $37.53 \mu$ while the length of the polar axis ranged from (33-41) $38.26 \mu$. The exine sculpture was scabrated and the tectum was reticulated. Its thickness reached up to $4.5 \mu$.

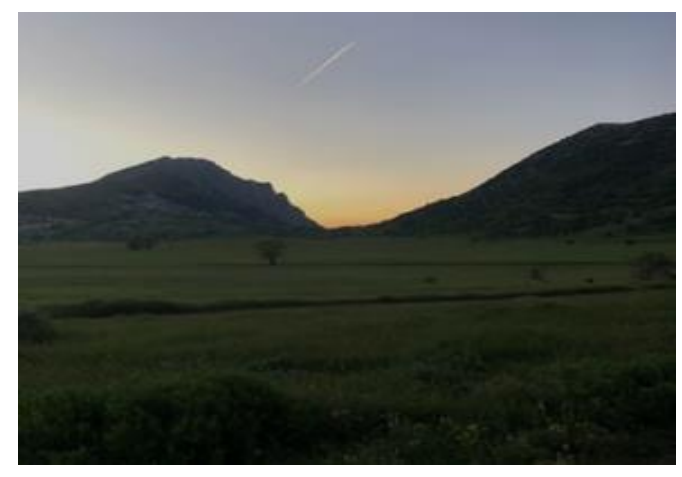

Figure 1 Valley of Zagoria (Kallajxhiu, N)

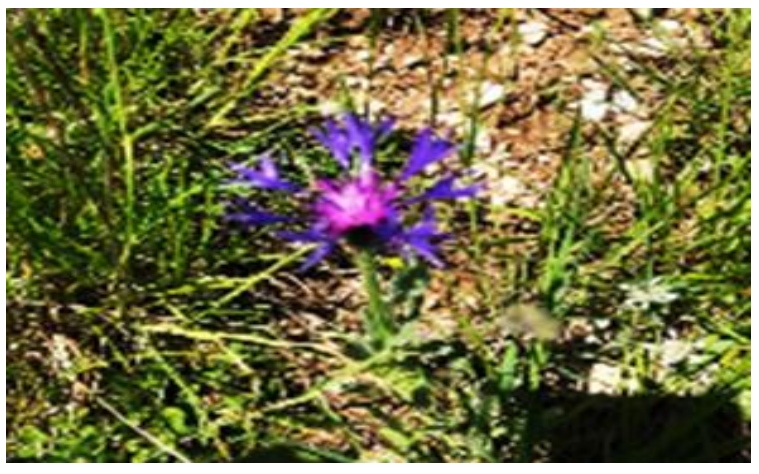

Figure 2 Photo of Centaurea epirota taken in its habitat

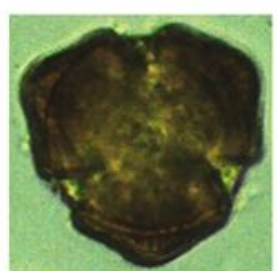

a

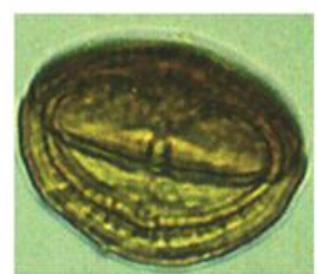

$\mathrm{b}$

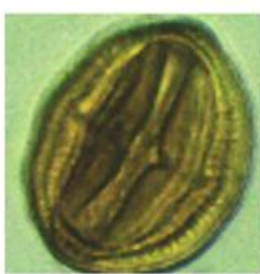

c

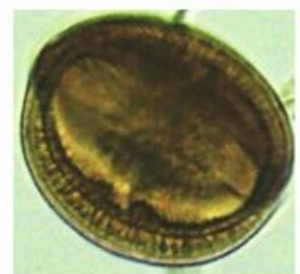

d

Figure 3 Microscopic photos of pollen grains of Centaurea epirota a: pollen grains in polar view; b, c, d: pollen grains in equatorial view (Source: Digital Microscope/Camera Software, magnification 400x, photo: Kallajxhiu, N)

To notice the differences and similarities in palynomorphological features, a comparison between the pollen grains of Centaurea epirota and Centaurea cyanus was made, a comparison which was taken from the albanian literature [9]. Numerical values of the dimensions of these two species are presented in the Tab. 1.

From the values in the table above, it is clear that the pollen grains width and length of Centaurea epirota are larger than those of Centaurea cyanus pollen grains while the colpi's and pore's sizes are smaller. Also, the distance between the colpi of Centaurea epirota is smaller $(15 \mu)$ than that of the other species $(20 \mu)$. 
Table 1 Average dimensions of pollen grains and the shape of exine in two species

\begin{tabular}{|l|c|c|c|c|c|c|l|}
\hline Species & $\begin{array}{l}\text { Length of } \\
\text { pollen }(\boldsymbol{\mu})\end{array}$ & $\begin{array}{l}\text { Width of } \\
\text { pollen }(\boldsymbol{\mu})\end{array}$ & $\begin{array}{l}\text { Length of } \\
\text { colpi }(\boldsymbol{\mu})\end{array}$ & $\begin{array}{l}\text { Length of } \\
\text { pori }(\boldsymbol{\mu})\end{array}$ & $\begin{array}{l}\text { Width of } \\
\text { pori }(\boldsymbol{\mu})\end{array}$ & Mesocolpium & $\begin{array}{l}\text { Shape of } \\
\text { exine }\end{array}$ \\
\hline $\begin{array}{l}\text { Centaurea } \\
\text { epirota }\end{array}$ & 38.26 & 37.53 & 19.43 & 3.35 & 7.3 & 15 & Scabrate \\
\hline $\begin{array}{l}\text { Centaurea } \\
\text { cyanus }\end{array}$ & 34.75 & 28.63 & 34.17 & 4.94 & 7.65 & 20 & Psilate \\
\hline
\end{tabular}

The exine layer of the examinated species is slightly thicker $(4.5 \mu)$ than that of Centaurea cyanus ( $4.19 \mu)$. It presents scabrate unlike that of Centaurea cyanus which is psilate.

\subsection{Palynomorphological description of Viola epirota (Halacs) Raus}

\section{Genus: Viola, Family: Violaceae}

Viola epirota is an endemic plant found in the Mountain Flora of Greece [25], spread in Epirus, along the southern border of our country within the district of Gjirokastra. It was found for the first time in Sopot mountain in 2007 (1400 m altitude), while in 2008 it was found in Murgana mountain, at an altitude of $1035 \mathrm{~m}$. Viola epirota is also widespread in Bureto, Çajup, Nemërçkë and Kërndërvica [2, 3].

The material studied was collected in the Çajup Mountain Area, in the valley of Zagoria.

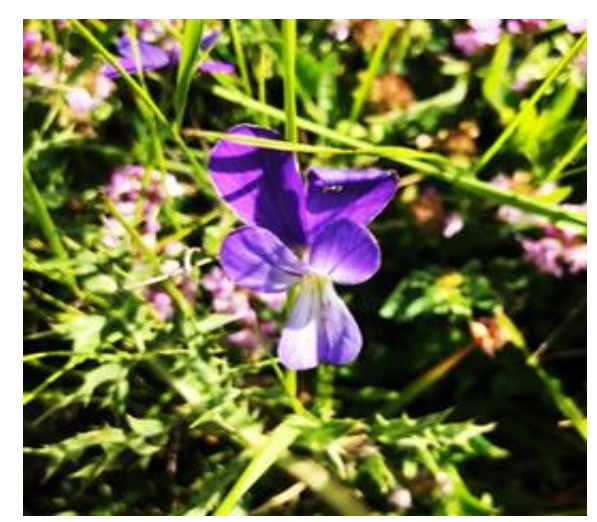

Figure 4 Photo of Viola epirota taken in its habitat (Kallajxhiu N)

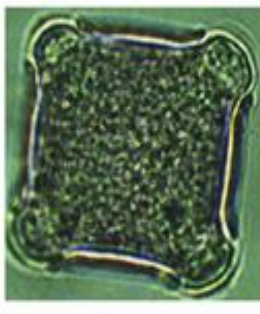

a

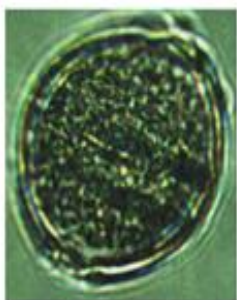

b

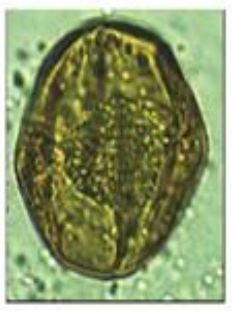

c

Figure 5 Microscopic photos of pollen grains of Viola epirota a: pollen grains in polar view; b, c: pollen grains in equatorial view

(Source: Digital Microscope/Camera Software, obtained at $400 \mathrm{x}$ magnification, photo: Kallajxhiu, N)

Pollen grains of Viola epirota were monads, radially symmetrical, 3-4 colporate, sometimes and 5 colporate, with spheroidal oval contours. The outline in the polar view was circular triangular or quadrangular, sometimes and 
pentagonal, and the outline in the equatorial view was oblate spheroidala. Colpi reached up the poles of the pollen grains. Colpus length ranged from 15-20 (18.44) $\mu$ and the distance between colpi varied from 21-31 (28.6) $\mu$. The pore was almost in the center of the colpi and its width went up to $16.2 \mu$. The exine had 2 layers and with a thickness of $4 \mu$. Exine sculpture was granulate. The pollen grains had a polar axis length ranging from 49-59 (53.09) $\mu$ and an equatorial axis length ranging from 50-58 (52.18) $\mu$. Figure 6 shows the average values of the pollen grains of 4 species of the genus Viola and the comparison between them.

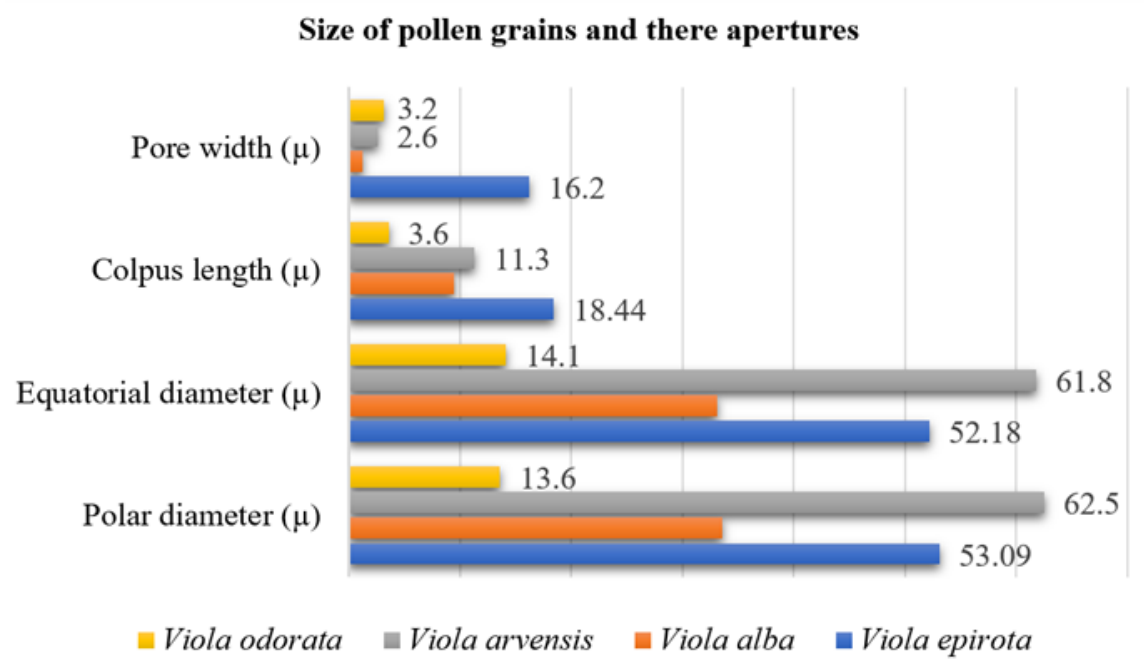

Figure 6 Graph of average values of pollen grains

From figure 6 it can be noticed that the pollen grains of Viola arvensis have larger dimensions in the polar and equatorial axis than those of the other three species. Viola epirota has larger dimensions than the other three species in terms of colpi length and pore width but has smaller dimensions in the length of the equatorial and polar axis compared to the Viola arvensis type. Viola odorata type has pollen grains smaller than the other three types.

According to the classification of pollen grains based on size [26, 27], it was found that Viola epirota $(52.18-53.09 \mu)$ and Viola arvensis (62.5-61.8 $\mu$ ) had large pollen grains. Viola odorata had pollen grains of a small size $(13.6-14.1 \mu)$ and Viola alba had medium-sized pollen grains (33.6-33.1 $\mu)$.

Exine ornamentation varies from granulate (Viola epirota), microreticulate (Viola alba), microspinule (Viola arvensis) to microgranulate (Viola odorata), (Tab. 2).

Table 2 Size and apertures data of pollen grains, shape of exine of taxa Viola

\begin{tabular}{|l|c|c|c|c|l|}
\hline Species & $\begin{array}{l}\text { Polar } \\
\text { diameter }(\boldsymbol{\mu})\end{array}$ & $\begin{array}{l}\text { Equatorial } \\
\text { diameter }(\boldsymbol{\mu})\end{array}$ & $\begin{array}{l}\text { Colpus } \\
\text { length }(\boldsymbol{\mu})\end{array}$ & $\begin{array}{l}\text { Pore } \\
\text { width }(\boldsymbol{\mu})\end{array}$ & Shape of exine \\
\hline Viola epirota & 53.09 & 52.18 & 18.44 & 16.2 & Granulate \\
\hline Viola alba & 33.6 & 33.1 & 9.5 & 1.2 & Microreticulate \\
\hline Viola arvensis & 62.5 & 61.8 & 11.3 & 2.6 & Microspinule \\
\hline Viola odorata & 13.6 & 14.1 & 3.6 & 3.2 & microgranulate \\
\hline
\end{tabular}

\section{Conclusion}

Based on the palynomorphological comparitive study of the species of genus Viola, it resulted that the one which had the smallest size of the pollen grains was Viola odorata while the largest dimensions in length and width of pollen grains were those of Viola arvensis. Viola epirota had furrow length and pore width greater than other species. Viola alba was presented with pores of a smaller width than all other species studied. 
Differences were also noticed in the form of exine. In the analysed specie, it varied from granulate to microreticulate (alba), microspinule (arvensis) and microgranulate (odorata).

The shape of pollen grains in equatorial view of the species was oblate-spheroidal to suboblate in the Viola genus and oval in Centaurea genus.

The pollen grains of Centaurea epirota were longer and wider but had smaller lengths and widths of pores and furrows than Centaurea cyanus.

\section{Compliance with ethical standards}

\section{Acknowledgments}

We want to thank the botanists who helped organize the expedition and determine the species found.

\section{Disclosure of conflict of interest}

All authors disclose that they have no conflict of interest.

\section{References}

[1] Kabo M. Physical geography of Albania. Vol.1-2. Science Academy. Tirana. 1991.

[2] Mahmutaj E, Shuka L, Xhulaj M, Hoda P, Mersinllari M. Rare and endemic plants in the Southern mountain ecosystems of Albania, their threats and diversity. Albanian Journal of Agricultural Sciences. 2015; 14 (1): 1-10.

[3] Malo S, Shuka L. Ecology, distribution and present status of Rare and Endangered plants of the Gjirokastra district. Scientific Bulletin, Natural Sciences Series. University of Shkodra. 2009; (59): 125-139.

[4] Malo S. Study of plant diversity in the district of Gjirokastra. [Ph.D. dissertation]. Tirana University; FNS. 2009.

[5] Vangjeli J, Ruci B, Mullaj A, Paparisto K, Qosja Xh. Flora of Albania. Vol. IV. Tirana. 2000.

[6] Pehlivan S. Pollen morphology of some Turkish endemic Centaurea. Grana. 1995; 34 (1): 29-38.

[7] Celik S, Uysal I, Menemen Y, Karabacak E. Morphology, Anatomy, Ecology, Pollen and Achene Structure of Centaurea consanguinea DC. (Sect. Acrolophus). International Journal of Botany. 2005; 1: 85-89.

[8] Özler H, Kaya Z, Pehlivan S. Pollen morphology of some Centaurea L., Psephellus cass. and cyanus miller taxa acta biologica cracoviensia Series Botanica. 2009; 51 (2): 53-66.

[9] Kallajxhiu N. Allergopallinological study of allergic plants of the district of Elbasan and allergies caused by them. Monograph. Elbasan, Albania. Rama Graf. 2011. 106 p.

[10] Shabestari ESB, Attar F, Riahi H, Sheidai M. Pollen morphology of Centaurea L. (Asteraceae) in Iran. Acta Botanica Brasilica. 2013; 27(4): 669-679.

[11] Qosja Xh, Paparisto K, Vangjeli J, Demiri M, Balza E, Marika A. Flora of Albania. Vol. II. Tirana. 1992.

[12] Erdtman G. Pollen morphology and plant taxonomy: Angiosperms. Chronica Botanica Co., Waltham, Massachusettes. 1952.

[13] Pettet A. Studies on British pansies I. chromosome numbers and pollen assemblages. Watsonia. 1964; 6: 39-50.

[14] Walker JW, Doyle JA. The bases of angiosperm phylogeny: Palynology. Annals of the Missouri Botanical Garden. 1975; 62: 664-723.

[15] Gorb OV. Pollen morphology of section Melanium Ging. of genus Viola L. of Ukraine (in Ukrainian). Ukrainian Botanical Journal. 1994; 51: 78-85.

[16] Pupuleku B, Kapidani G, Naqellari P, Gjeta E, Gjorga S, Kokiçi E. Compared palynomorphological characteristics of pollens grains of three honey plants of the family Violaceae. Bulletin of Natural Sciences, University of Elbasan, Rama Graf. 2020; 46 (2): 70-77.

[17] Mehrvarz SHS, Yousefi N, Mohammadi M, Marcussen TH. Pollen studies in the genius Viola (Violaceae) from Iran. Acta Bot. Croat. 2014; 73(1): 93-106. 
[18] Kapidani G. Problems of Palinological Terminology, Dictionary of Palinology. Elbasan. Albania. Printing House "Sejko". 2004; 152 p.

[19] Erdtman G. The acetolysis method. Svensk Botanicheskii Tidskrift. 1960; 54: 561-564.

[20] Avetisjan BM. Uproshennij acetolinij metod obrabotniki. Botanicheskii Zhurnal. 1950; 35(4): $385-386$.

[21] Smoljaninova LA, Gollubkova VF. LAK Metodike issledovani pilci Doklady Akademia Nauk SSSR T LXXXVIII. 1953; 1: 125-126.

[22] Kisser J. Bemerkungen zum Einschluss in Glycerin-Gelatine. Z. wiss. Mikr. Berlin. 1935; 1-51.

[23] Ducker CS, Knox BR. Pollen and people. Biotechnology and ecology of pollen, New York. 1985; 399-404.

[24] Surova TD, Gumbatov ZJ. Ultrastruktura obovllocka pilcevi zeren Kavkazni prectavitel Taxus baccata (Taxaceae), Bor. Zhurnal. T. 71. 1986; 7: 886-888.

[25] Strid A, Kit T. Mountain flora of Greece. Vo. 2. Cambridge University Press. 1985; 609-629.

[26] Walker JW, Doyle JA. The bases of angiosperm phylogeny: Palynology. Annals of the Missouri Botanical Garden. 1975; 62: 664-723.

[27] Kapidani G. Basics of palinology. Spores and pollen of some plants in Albania. Monograph. Elbasan. Albania. Printing House "Sejko", 1996; 184 p. 